\title{
Novel Tryptophan Derivatives as Potentially Effective Therapeutic Drugs to Treat Bone Diseases
}

\author{
Nobuo Suzuki ${ }^{1,}$,, Masanori Somei ${ }^{1}$, Azusa Seki ${ }^{2}$, Toshio Sekiguchi ${ }^{1}$, Yoshiaki Tabuchi ${ }^{3}$, \\ Hiroyuki Mishima $^{4}$, Yoichi Kase ${ }^{1}$, Atsushi Kaminishi ${ }^{1}$, Koji Yachiguchi ${ }^{1}$, Kei-ichiro Kitamura ${ }^{5}$, \\ Yuji Oshima $^{6}$, Kazuichi Hayakawa ${ }^{7}$, Sachiko Yano ${ }^{8}$, Atsuhiko Hattori ${ }^{9}$ \\ ${ }^{1}$ Noto Marine Laboratory, Institute of Nature and Environmental Technology, Kanazawa University, Housu-gun, Ishikawa 927-0553, Japan \\ ${ }^{2}$ HAMRI Co. Ltd., Koga, Ibaraki 306-0101, Japan \\ ${ }^{3}$ Division of Molecular Genetics Research, Life Science Research Center, University of Toyama, Toyama, Toyama 930-0194, Japan \\ ${ }^{4}$ Department of Medical Hygiene, Dental Hygiene Course, Kochi Gakuen College, Kochi, Kochi 780-0955, Japan \\ ${ }^{5}$ Faculty of Health Sciences, Institute of Medical, Pharmaceutical and Health Sciences, Kanazawa University, Kodatsuno, Ishikawa 920-0942, \\ Japan \\ ${ }^{6}$ Faculty of Agriculture, Kyushu University, Hakozaki, Fukuoka 812-8581, Japan \\ ${ }^{7}$ Faculty of Pharmaceutical Sciences, Institute of Medical, Pharmaceutical and Health Sciences, Kanazawa University, Kakuma, Ishikawa \\ 920-1192, Japan \\ ${ }^{8}$ Japan Aerospace Exploration Agency, Tsukuba, Ibaraki 305-8505, Japan \\ ${ }^{9}$ Department of Biology, College of Liberal Arts and Sciences, Tokyo Medical and Dental University, Ichikawa, Chiba 272-0827, Japan
}

\section{Email address:}

nobuos@staff.kanazawa-u.ac.jp (N. Suzuki)

\section{To cite this article:}

Nobuo Suzuki, Masanori Somei, Azusa Seki, Toshio Sekiguchi, Yoshiaki Tabuchi, Hiroyuki Mishima, Yoichi Kase, Atsushi Kaminishi, Koji Yachiguchi, Kei-ichiro Kitamura, Yuji Oshima, Kazuichi Hayakawa, Sachiko Yano, Atsuhiko Hattori. Novel Tryptophan Derivatives as Potentially Effective Therapeutic Drugs to Treat Bone Diseases. American Journal of Life Sciences. Special Issue: Biology and Medicine of Peptide and Steroid Hormones. Vol. 3, No. 3-2, 2015, pp. 31-38. doi: 10.11648/j.ajls.s.2015030302.16

\begin{abstract}
We recently developed an in vitro assay to study bone metabolism using fish scales that contain osteoblasts, osteoclasts, and calcified bone matrix, all of which are similar to those found in mammalian membrane bone. Using the fish scale assay, we previously reported that the functions of calcemic hormones such as calcitonin and parathyroid hormone in osteoblasts and osteoclasts were similar to those in mammals. Therefore, our fish scale in vitro assay system is suitable for the screening of potential bone-forming compounds. In an attempt to develop molecules that increase bone mass, novel tryptophan derivatives were synthesized and screened for effects on osteoblasts and osteoclasts using the fish scale model. As a result, novel tryptophan derivatives with the ability to possibly increase bone formation were identified, but they had no effect on osteoclast activity. Among the identified derivatives, $(S)-(+)-N$-acetyl-2,4,6-tribromo-5-methoxytryptophan methyl ester (BTryp) had the strongest activity on osteoblasts. The effect of this chemical on bone formation was confirmed in an ovariectomized (OVX) rat model of post-menopausal osteoporosis. Our data indicated that both trabecular bone mineral density and stress-strain index of the femoral metaphysis of BTryp-treated OVX rats were significantly higher than those of OVX rats. This study identified a bromotryptophan derivative that may have potential use in the treatment of bone diseases, such as osteoporosis.
\end{abstract}

Keywords: Tryptophan Derivatives, Osteoblasts, Osteoclasts, Scales, Bone Diseases, Ovariectomized Rats

\section{Introduction}

Teleost scale is a calcified tissue that contains osteoblasts (bone formative cells), osteoclasts (bone resorptive cells), and bone matrix of two layers (bony layer: a thin, well-calcified external layer; fibrillary layer: a thick, partially calcified layer) [1-8]. These features are very similar to those found in mammalian membrane bone. In the goldfish scales as well as mammalian bone, furthermore, mRNA expression of the osteoclast-specific markers tartrate-resistant acid phosphatase (TRAP) and cathepsin $\mathrm{K}$ has been detected in these osteoclasts by whole-mount in situ hybridization [8]. We have previously identified osteoblasts in this tissue and detected osteoblast-specific markers, such as alkaline phosphatase 
(ALP), type 1 collagen, the receptor activator of the NF- $\mathrm{BB}$ ligand (RANKL), osterix, runt-related transcription factor 2 (Runx2), and osteocalcin [7, 9]. The scales of teleosts contain as much as $20 \%$ of the total body calcium [10]. It has been reported that fish scale contains a more abundant calcium store than vertebra, jaw, and otolith, judging from the study of ${ }^{45} \mathrm{Ca}$-prelabeled scale, vertebra, jaw, and otolith of goldfish and killifish [11]. Vertebral bone has an important role in swimming, since when the vertebral bone is fractured, the fish cannot swim. Therefore, most fishes use their scales as a calcium source.

Using the fish scale as a model system, we developed an in vitro assay where the activities of ALP and TRAP act as respective indicators of each activity in osteoclasts and osteoblasts [2, 3]. We have previously reported that the function of some calcemic hormones such as parathyroid hormone [7] and calcitonin [2] in osteoblasts and osteoclasts in our scale model were similar to those in mammalian bone. Therefore, this fish scale in vitro assay system is suitable for the screening of potential bone-forming compounds.

In the present study, we developed novel tryptophan derivatives that increase bone mass, and examined the effects of these chemicals on osteoblasts and osteoclasts using the fish scale in vitro assay. To confirm the results of the in vitro assay, the effect of the strongest tryptophan derivative on bone metabolism was examined in vivo using ovariectomized (OVX) rats as a model animal of post-menopausal osteoporosis.

\section{Materials and Methods}

\subsection{Synthesis of Novel Tryptophan Derivatives}

To analyze novel compounds, melting points were determined on a Yanagimoto micro melting point apparatus and were uncorrected. Infrared (IR) spectra were determined with an IR-420 (Shimadzu Co., Kyoto, Japan) or FT-720 spectrophotometer (Horiba Ltd., Kyoto, Japan) and proton nuclear magnetic resonance ( $\left.{ }^{1} \mathrm{H}-\mathrm{NMR}\right)$ spectra with a spectrometer (GSX-500, JEOL Ltd., Tokyo, Japan), with tetramethylsilane (TMS) as an internal standard. Chemical shifts are reported in $\delta$ relative to TMS. Mass spectra (MS) were recorded on a SX-102A spectrometer (JEOL Ltd.). Column chromatography was performed on silica gel $\left(\mathrm{SiO}_{2}\right.$, 100-200 mesh, from Kanto Chemical Co. Inc.) throughout the present study.

Bromination of $(S)-(+)-N$-acetyl-5-methoxytryptophan methyl ester [12] (1) in $\mathrm{AcOH}-\mathrm{NaOAc}$ afforded an inseparable mixture of $(S)-(+)-N$-acetyl-2,4,7-tribromo5-methoxytryptophan methyl ester (2) and $(S)-(+)-N$-acetyl-2, 6-dibromo-5-methoxytryptophan methyl ester (3), and (S)-(+)- $N$-acetyl-2, 4, 6-tribromo- 5-methoxytryptophan methyl ester (4) with a yield of $52 \%$ (Fig. 1 ). The ratio of 2 and 3 in the mixture was found to be $2: 1$ by analysis of its ${ }^{1} \mathrm{H}-\mathrm{NMR}$ spectrum. Based on the ratio, yields of 2 and 3 were calculated to be $18 \%$ and $11 \%$, respectively. The attempt for the selective production of 4 from 1 was examined under various reaction conditions; however, the attempt was unsuccessful.

The isolations of 2 and 3 were performed as follows. The 2:1 mixture of 2 and 3 was reacted with di-t-butyl dicarbonate in the presence of dimethylaminopyridine (DMAP) to produce (S)-(+)- $N$-acetyl-2,6-dibromo-1-t-butoxycarbonyl-5-methoxy tryptophan methyl ester (5) and 2. The bromine atom at the 7-position of 2 effected severe steric hindrance and hindered the reaction at the 1-position leaving 2 unaffected. Subsequent treatment of 5 with $10 \%$ aqueous trifluoroacetic acid removed the tert-butoxycarbonyl group at the 1-position culminating in the formation of 3 with a yield of $70 \%$.

The reaction of 4 with di-tert-butyl dicarbonate in the presence of DMAP provided $(S)-(+)-N$-acetyl-2,4,6tribromo-1- $t$-butoxycarbonyl-5-methoxytryptophan methyl ester $(6, t$ BocBTryp) with a yield of $98 \%$. Similarly, the reactions of 4 with allyl, propargyl, and benzyl bromides in the presence of $\mathrm{K}_{2} \mathrm{CO}_{3}$ gave the corresponding 1-allyl- (7, AllylBTryp), 1-propargyl- (8, PropargylBTryp), and 1-benzylderivatives $(9$, BnBTryp) with 99,94 , and $96 \%$ yields, respectively.

Synthesis of $(S)-(+)-N$-acetyl-2,4,7-tribromo$(S)-(+)-N$-acetyl-2,6-dibromo- (3), and $(S)-(+)-N$-acetyl-2,4,6tribromo-5-methoxytryptophan methyl ester (4, BTryp) from $(S)-(+)-N$-acetyl-5-methoxytryptophan methyl ester (1) - A solution of $1(56.6 \mathrm{mg}, 0.20 \mathrm{mmol})$ in $4.5 \mathrm{~mL}$ of $\mathrm{AcOH}$ was mixed with a solution of $\mathrm{Br}_{2}(1.0 \mathrm{~mL}, 0.59 \mathrm{mmol})$, separately prepared by dissolving $458.0 \mathrm{mg}$ of $\mathrm{Br}_{2}$ and $41.8 \mathrm{mg}$ of $\mathrm{NaOAc}$ in $5.0 \mathrm{~mL}$ of $\mathrm{AcOH}$, and the mixture was stirred at room temperature for $30 \mathrm{~min}$. After the addition of $10 \%$ aqueous $\mathrm{Na}_{2} \mathrm{~S}_{2} \mathrm{O}_{2}$, the mixture was made alkaline by adding $40 \%$ aqueous $\mathrm{NaOH}$ under ice cooling and extracted with $\mathrm{CHCl}_{3}-$ $\mathrm{MeOH}(95: 5, \mathrm{v} / \mathrm{v})$. The extract was washed with brine, dried over $\mathrm{Na}_{2} \mathrm{SO}_{4}$, and evaporated under reduced pressure to leave a yellow solid, which was purified by column chromatography on $\mathrm{SiO}_{2}$ with $\mathrm{CHCl}_{3}-\mathrm{MeOH}(99.5: 0.5, \mathrm{v} / \mathrm{v})$ to give an inseparable $2: 1$ mixture $(28.4 \mathrm{mg})$ of 2 and 3 , and $4(53.7 \mathrm{mg}$, $52 \%$ ) in the order of elution. 4: mp $198-199^{\circ} \mathrm{C}$ (colorless granules, recrystallized from AcOEt). IR (KBr): 3307, 1730, $1647,1556,1300,1232,1028 \mathrm{~cm}^{-1} .{ }^{1} \mathrm{H}-\mathrm{NMR}\left(\mathrm{CDCl}_{3}\right) \delta: 1.88$ $(3 \mathrm{H}, \mathrm{s}), 3.29(1 \mathrm{H}, \mathrm{dd}, J=9.8,14.6 \mathrm{~Hz}), 3.58(1 \mathrm{H}, \mathrm{dd}, J=5.2$, $14.6 \mathrm{~Hz}), 3.77(3 \mathrm{H}, \mathrm{s}), 3.88(3 \mathrm{H}, \mathrm{s}), 5.01(1 \mathrm{H}, \mathrm{ddd}, J=5.2,8.6$, $9.8 \mathrm{~Hz}$, changed to dd, $J=5.2,9.8 \mathrm{~Hz}$ on addition of $\mathrm{D}_{2} \mathrm{O}$ ), $6.17\left(1 \mathrm{H}\right.$, br d, $J=8.6 \mathrm{~Hz}$, disappeared on addition of $\left.\mathrm{D}_{2} \mathrm{O}\right)$, $7.37(1 \mathrm{H}, \mathrm{s}), 8.70\left(1 \mathrm{H}\right.$, br s, disappeared on addition of $\left.\mathrm{D}_{2} \mathrm{O}\right)$. MS $m / z$ : $530\left(\mathrm{M}^{+}\right), 528\left(\mathrm{M}^{+}\right), 526\left(\mathrm{M}^{+}\right), 524\left(\mathrm{M}^{+}\right)$. Anal. Calcd for $\mathrm{C}_{15} \mathrm{H}_{15} \mathrm{Br}_{3} \mathrm{~N}_{2} \mathrm{O}_{4}$ : C, 34.19; H, 2.87; N, 5.32. Found: C, 34.24; H, 2.89; N, 5.18. Optical Rotation $[\alpha]_{\mathrm{D}}{ }^{26}+14.8^{\circ}$ (DMSO, c 0.200$) .[\alpha]_{\mathrm{D}}{ }^{27}+1.47^{\circ}(\mathrm{MeOH}$, c 0.204$) .[\alpha]_{\mathrm{D}}{ }^{28}$ $+4.4^{\circ}\left(\mathrm{CHCl}_{3}, \mathrm{c} 0.203\right)$.

Synthesis of $(S)-(+)-N$-acetyl-2,4,6-tribromo-1$t$-butoxycarbonyl-5-methoxytryptophan methyl ester (6, $t$ BocBTryp) from 4 - A solution of $4(49.3 \mathrm{mg}, 0.09 \mathrm{mmol})$ in $\mathrm{CHCl}_{3}(10.0 \mathrm{~mL})$ was mixed with a solution of dimethylaminopyridine $(3.4 \mathrm{mg}, 0.03 \mathrm{mmol})$ and di-t-butyl dicarbonate $(30.6 \mathrm{mg}, 0.14 \mathrm{mmol})$ in $\mathrm{CHCl}_{3}(1.0 \mathrm{~mL})$, and the mixture was stirred at room temperature for $30 \mathrm{~min}$. After 
evaporation of the solvent under reduced pressure, the resultant yellow residue was purified by column chromatography on $\mathrm{SiO}_{2}$ with $\mathrm{CHCl}_{3}-\mathrm{MeOH}(99: 1, \mathrm{v} / \mathrm{v})$ to give 6 (57.5 mg, 98\%). 6: $\mathrm{mp} 126-128^{\circ} \mathrm{C}$ (colorless needles, recrystallized from $\mathrm{CHCl}_{3}$-hexane). IR (KBr): 3435, 1759, 1732, 1651, 1396, 1275, 1159, $1111 \mathrm{~cm}^{-1} .{ }^{1} \mathrm{H}-\mathrm{NMR}\left(\mathrm{CDCl}_{3}\right) \delta$ : $1.69(9 \mathrm{H}, \mathrm{s}), 1.89(3 \mathrm{H}, \mathrm{s}), 3.38(1 \mathrm{H}, \mathrm{dd}, J=10.1,14.3 \mathrm{~Hz})$, $3.65(1 \mathrm{H}, \mathrm{dd}, J=5.2,14.3 \mathrm{~Hz}), 3.75(3 \mathrm{H}, \mathrm{s}), 3.90(3 \mathrm{H}, \mathrm{s}), 5.07$ $(1 \mathrm{H}, \mathrm{ddd}, J=5.2,8.5,10.1 \mathrm{~Hz}$, changed to dd, $J=5.2,10.1 \mathrm{~Hz}$ on addition of $\left.\mathrm{D}_{2} \mathrm{O}\right), 6.14(1 \mathrm{H}$, br d, $J=8.5 \mathrm{~Hz}$, disappeared on addition of $\left.\mathrm{D}_{2} \mathrm{O}\right), 8.39(1 \mathrm{H}, \mathrm{s})$. MS $m / z: 630\left(\mathrm{M}^{+}\right), 628\left(\mathrm{M}^{+}\right)$, $626\left(\mathrm{M}^{+}\right), 624\left(\mathrm{M}^{+}\right)$. Anal. Calcd for $\mathrm{C}_{20} \mathrm{H}_{23} \mathrm{Br}_{3} \mathrm{~N}_{2} \mathrm{O}_{6}$ : C, 38.30; H, 3.70; N, 4.47. Found: C, 38.18; H, 3.74; N, 4.45. Optical Rotation $[\alpha]_{\mathrm{D}}{ }^{24}+3.3^{\circ}\left(\mathrm{CHCl}_{3}, \mathrm{c} 0.200\right)$.

Synthesis of $(S)$-(+)- $N$-acetyl-1-allyl-2,4,6-tribromo5-methoxytryptophan methyl ester (7, AllylBTryp) from 4 A solution of $4 \quad(39.8 \quad \mathrm{mg}, \quad 0.08 \quad \mathrm{mmol})$ in $\mathrm{N}, \mathrm{N}$-dimethylformamide (DMF, $2.5 \mathrm{~mL}$ ) was mixed with $\mathrm{K}_{2} \mathrm{CO}_{3}(36.5 \mathrm{mg}, 0.26 \mathrm{mmol})$ and allyl bromide $(0.13 \mathrm{~mL}, \mathrm{~d}=$ $1.398,1.51 \mathrm{mmol})$. After stirring at room temperature for 30 min, water was added, and the whole reaction mixture was extracted with AcOEt. The extract was washed with brine, dried over $\mathrm{Na}_{2} \mathrm{SO}_{4}$, and evaporated under reduced pressure to leave yellow oil. Purification by column-chromatography on $\mathrm{SiO}_{2}$ with $\mathrm{CHCl}_{3}$ produced 7 (42.4 mg, 99\%). 7: mp 191$192^{\circ} \mathrm{C}$ (colorless needles, recrystallized from AcOEt). IR (KBr): 3303, 1732, 1645, 1547, 1228, $1016 \mathrm{~cm}^{-1}$. ${ }^{1} \mathrm{H}-\mathrm{NMR}$ $\left(\mathrm{CDCl}_{3}\right) \delta: 1.86(3 \mathrm{H}, \mathrm{s}), 3.34(1 \mathrm{H}, \mathrm{dd}, J=9.8,14.7 \mathrm{~Hz}), 3.62$ $(1 \mathrm{H}, \mathrm{dd}, J=5.4,14.7 \mathrm{~Hz}), 3.74(3 \mathrm{H}, \mathrm{s}), 3.89(3 \mathrm{H}, \mathrm{s}), 4.75(2 \mathrm{H}$, $\mathrm{m}), 4.83(1 \mathrm{H}, \mathrm{d}, J=17.1 \mathrm{~Hz}), 5.01(1 \mathrm{H}, \mathrm{ddd}, J=5.4,8.7,9.8$ $\mathrm{Hz}$, changed to dd, $J=5.4,9.8 \mathrm{~Hz}$ on addition of $\left.\mathrm{D}_{2} \mathrm{O}\right), 5.19$ $(1 \mathrm{H}, \mathrm{d}, J=10.3 \mathrm{~Hz}), 5.86(1 \mathrm{H}, \mathrm{tdd}, J=4.8,10.3,17.1 \mathrm{~Hz})$, $6.12\left(1 \mathrm{H}\right.$, br d, $J=8.7 \mathrm{~Hz}$, disappeared on addition of $\left.\mathrm{D}_{2} \mathrm{O}\right)$, $7.41(1 \mathrm{H}, \mathrm{s})$. MS m/z: $570\left(\mathrm{M}^{+}\right), 568\left(\mathrm{M}^{+}\right), 566\left(\mathrm{M}^{+}\right), 564\left(\mathrm{M}^{+}\right)$ Anal. Calcd for $\mathrm{C}_{18} \mathrm{H}_{19} \mathrm{Br}_{3} \mathrm{~N}_{2} \mathrm{O}_{4}$ : C, 38.12; H, 3.38; N, 4.94. Found: $\mathrm{C}, 37.97 ; \mathrm{H}, 3.43 ; \mathrm{N}, 4.86$. Optical Rotation $[\alpha]_{\mathrm{D}}{ }^{26}$ $+13.8^{\circ}\left(\mathrm{CHCl}_{3}\right.$, c 0.203$)$.

Synthesis of $(S)-(+)-N$-acetyl-2,4,6-tribromo5-methoxy-1-propargyltryptophan methyl ester (8, PropargylBTryp) from 4 - A solution of $4(23.6 \mathrm{mg}, 0.04$ mmol) in DMF $(2.0 \mathrm{~mL})$ was mixed with $\mathrm{K}_{2} \mathrm{CO}_{3}(21.6 \mathrm{mg}$, $0.16 \mathrm{mmol})$ and propargyl bromide $(0.08 \mathrm{~mL}, \mathrm{~d}=1.335,0.9$ $\mathrm{mmol}$ ). After stirring at room temperature for $30 \mathrm{~min}$, water was added, and the whole reaction mixture was extracted with AcOEt. The extract was washed with brine, dried over $\mathrm{Na}_{2} \mathrm{SO}_{4}$, and evaporated under reduced pressure to leave pink oil. Purification by column-chromatography on $\mathrm{SiO}_{2}$ with $\mathrm{CHCl}_{3}$ produced 8 (23.9 $\mathrm{mg}, 94 \%)$. 8: $\mathrm{mp} 284-285^{\circ} \mathrm{C}$ (decomp., measured with a sealed tube, colorless needles, recrystallized from $\left.\mathrm{CHCl}_{3}-\mathrm{MeOH}\right)$. IR (KBr): 3284, 3224, 2114, 1724, 1647 , $1552,1230,1016 \mathrm{~cm}^{-1} .{ }^{1} \mathrm{H}-\mathrm{NMR}$ (DMSO-d $\left.d_{6}\right) \delta: 1.82(3 \mathrm{H}, \mathrm{s})$, $3.28(1 \mathrm{H}, \mathrm{dd}, J=7.1,14.9 \mathrm{~Hz}), 3.33(1 \mathrm{H}, \mathrm{dd}, J=8.7,14.9 \mathrm{~Hz})$, $3.33(1 \mathrm{H}, \mathrm{t}, J=2.4 \mathrm{~Hz}), 3.48(3 \mathrm{H}, \mathrm{s}), 3.80(3 \mathrm{H}, \mathrm{s}), 4.47(1 \mathrm{H}$, ddd, $J=7.1,7.1,8.7 \mathrm{~Hz}$, changed to dd, $J=7.1,8.7 \mathrm{~Hz}$ on addition of $\left.\mathrm{D}_{2} \mathrm{O}\right), 5.13(2 \mathrm{H}, \mathrm{dt}, J=2.4,4.2 \mathrm{~Hz}), 8.02(1 \mathrm{H}, \mathrm{s})$, $8.44\left(1 \mathrm{H}\right.$, br d, $J=7.1 \mathrm{~Hz}$, disappeared on addition of $\left.\mathrm{D}_{2} \mathrm{O}\right)$. MS $m / z$ : $568\left(\mathrm{M}^{+}\right), 566\left(\mathrm{M}^{+}\right), 564\left(\mathrm{M}^{+}\right), 562\left(\mathrm{M}^{+}\right)$. Anal. Calcd for $\mathrm{C}_{18} \mathrm{H}_{17} \mathrm{Br}_{3} \mathrm{~N}_{2} \mathrm{O}_{4}$ : C, 38.26; H, 3.03; N, 4.96. Found: C, $38.11 ; \mathrm{H}, 3.12 ; \mathrm{N}, 4.83$. Optical Rotation $[\alpha]_{\mathrm{D}}{ }^{24}+7.7^{\circ}$ (DMSO, c 0.202 ).

Synthesis of $(S)-(+)-N$-acetyl-1-benzyl-2,4,6-tribromo5-methoxytryptophan methyl ester (9, BnBTryp) from $4-\mathrm{A}$ solution of $4(19.6 \mathrm{mg}, 0.04 \mathrm{mmol})$ in DMF $(1.5 \mathrm{~mL})$ was mixed with $\mathrm{K}_{2} \mathrm{CO}_{3}(18.0 \mathrm{mg}, 0.13 \mathrm{mmol})$ and benzyl bromide $(0.09 \mathrm{~mL}, \mathrm{~d}=1.44,0.7 \mathrm{mmol})$. After stirring at room temperature for $30 \mathrm{~min}$, water was added, and the whole reaction mixture was extracted with AcOEt-MeOH (95:5, $\mathrm{v} / \mathrm{v}$ ). The extract was washed with brine, dried over $\mathrm{Na}_{2} \mathrm{SO}_{4}$, and evaporated under reduced pressure to leave yellow oil. Preparative thin-layer chromatography was performed on $\mathrm{SiO}_{2}$ with $\mathrm{CHCl}_{3}-\mathrm{MeOH}(99: 1, \mathrm{v} / \mathrm{v})$ as a developing solvent. Extraction of the band having an $R f$ value of 0.18 to 0.29 with $\mathrm{CHCl}_{3}-\mathrm{MeOH}(95: 5, \mathrm{v} / \mathrm{v})$ afforded 9 (22.0 mg, 96\%). 9: mp 226-227 ${ }^{\circ} \mathrm{C}$ (colorless needles, recrystallized from $\left.\mathrm{MeOH}\right)$. IR (KBr): 3298, 1732, 1643, 1550, 1414, 1230, $1018 \mathrm{~cm}^{-1}$. ${ }^{1} \mathrm{H}-\mathrm{NMR}$ (DMSO- $\left.d_{6}\right) \delta: 1.80(3 \mathrm{H}, \mathrm{s}), 3.28(1 \mathrm{H}, \mathrm{dd}, J=7.1$, $14.4 \mathrm{~Hz}), 3.40(1 \mathrm{H}, \mathrm{dd}, J=8.5,14.7 \mathrm{~Hz}$, disappeared on addition of $\left.\mathrm{D}_{2} \mathrm{O}\right), 3.47(3 \mathrm{H}, \mathrm{s}), 3.79(3 \mathrm{H}, \mathrm{s}), 4.55(1 \mathrm{H}, \mathrm{ddd}, J=$ $7.1,7.1,8.5 \mathrm{~Hz}$, changed to $\mathrm{dd}, J=7.1,8.5 \mathrm{~Hz}$ on addition of $\left.\mathrm{D}_{2} \mathrm{O}\right), 5.53(2 \mathrm{H}, \mathrm{s}), 6.96(2 \mathrm{H}, \mathrm{d}, J=7.1 \mathrm{~Hz}), 7.25(1 \mathrm{H}, \mathrm{t}, J=$ $7.1 \mathrm{~Hz}), 7.31(2 \mathrm{H}, \mathrm{t}, J=7.1 \mathrm{~Hz}), 7.90(1 \mathrm{H}, \mathrm{s}), 8.45(1 \mathrm{H}, \mathrm{d}, J=$ $7.1 \mathrm{~Hz}$, disappeared on addition of $\left.\mathrm{D}_{2} \mathrm{O}\right)$. MS $m / z: 620\left(\mathrm{M}^{+}\right)$, $618\left(\mathrm{M}^{+}\right), 616\left(\mathrm{M}^{+}\right), 614\left(\mathrm{M}^{+}\right)$. Anal. Calcd for $\mathrm{C}_{22} \mathrm{H}_{21} \mathrm{Br}_{3} \mathrm{~N}_{2} \mathrm{O}_{4}$ : C, 42.82; H, 3.43; N, 4.54. Found: C, 42.69; H, 3.47; N, 4.56. Optical Rotation $[\alpha]_{\mathrm{D}}{ }^{24}+8.3^{\circ}\left(\mathrm{CHCl}_{3}, \mathrm{c} 0.204\right)$.

Synthesis of $(S)-(+)-N$-acetyl-2,6-dibromo-1$t$-butoxycarbonyl-5-methoxytryptophan methyl ester (5) from a mixture of 2 and 3 , and separation of $2-A$ solution of the inseparable 2:1 mixture (judged from ${ }^{1} \mathrm{H}-\mathrm{NMR}, 93.3 \mathrm{mg}$ ) of 2 and 3 in $\mathrm{CHCl}_{3}(10.0 \mathrm{~mL})$ was mixed with a solution of dimethylaminopyridine $(9.6 \mathrm{mg}, 0.08 \mathrm{mmol}, 0.5$ equivalents assuming that the whole mixture was 2) and di-t-butyl dicarbonate $(68.9 \mathrm{mg}, 0.31 \mathrm{mmol}, 2.0$ equivalents assuming that the whole mixture was 2) in $\mathrm{CHCl}_{3}(1.0 \mathrm{~mL})$. The mixture was stirred at room temperature for $10 \mathrm{~h}$. After evaporation of the solvent under reduced pressure, the resultant yellow residue was purified by column chromatography on $\mathrm{SiO}_{2}$ with $\mathrm{CHCl}_{3}-\mathrm{MeOH}(99: 1, \mathrm{v} / \mathrm{v})$ to give $5(39.0 \mathrm{mg})$ and $2(62.0 \mathrm{mg})$ in the order of elution. $2: \mathrm{mp} 218-220^{\circ} \mathrm{C}$ (colorless prisms, recrystallized from $\mathrm{CHCl}_{3}-$ hexane). IR ( $\mathrm{KBr}$ ): 3435, 3303, $1728,1653,1552 \mathrm{~cm}^{-1} .{ }^{1} \mathrm{H}-\mathrm{NMR}\left(\mathrm{CDCl}_{3}\right) \delta: 1.87(3 \mathrm{H}, \mathrm{s}), 3.31$ $(1 \mathrm{H}, \mathrm{dd}, J=10.0,14.6 \mathrm{~Hz}), 3.58(1 \mathrm{H}, \mathrm{dd}, J=5.1,14.6 \mathrm{~Hz})$, $3.75(3 \mathrm{H}, \mathrm{s}), 3.91(3 \mathrm{H}, \mathrm{s}), 5.00(1 \mathrm{H}, \mathrm{ddd}, J=5.1,8.5,10.0 \mathrm{~Hz}$, changed to dd, $J=5.1,10.0 \mathrm{~Hz}$ on addition of $\left.\mathrm{D}_{2} \mathrm{O}\right), 6.12(1 \mathrm{H}$, br d, $J=8.5 \mathrm{~Hz}$, disappeared on addition of $\left.\mathrm{D}_{2} \mathrm{O}\right), 7.05(1 \mathrm{H}, \mathrm{s})$, $8.31\left(1 \mathrm{H}\right.$, br s, disappeared on addition of $\left.\mathrm{D}_{2} \mathrm{O}\right)$. MS $m / z: 530$ $\left(\mathrm{M}^{+}\right), 528\left(\mathrm{M}^{+}\right), 526\left(\mathrm{M}^{+}\right), 524\left(\mathrm{M}^{+}\right)$. Anal. Calcd for $\mathrm{C}_{15} \mathrm{H}_{15} \mathrm{Br}_{3} \mathrm{~N}_{2} \mathrm{O}_{4}$ : C, 34.19; H, 2.87; N, 5.32. Found: C, 34.00; $\mathrm{H}, 2.91 ; \mathrm{N}, 5.22$. Optical Rotation $[\alpha]_{\mathrm{D}}{ }^{24}+5.1^{\circ}\left(\mathrm{CHCl}_{3}\right.$, c 0.207). 5: colorless oil. IR (film): 3286, 2981, 1743, 1735, $1654 \mathrm{~cm}^{-1} .{ }^{1} \mathrm{H}-\mathrm{NMR}\left(\mathrm{CDCl}_{3}\right) \delta: 1.70(9 \mathrm{H}, \mathrm{s}), 1.99(3 \mathrm{H}, \mathrm{s})$, $3.21(1 \mathrm{H}, \mathrm{dd}, J=7.6,15.0 \mathrm{~Hz}), 3.24(1 \mathrm{H}, \mathrm{dd}, J=5.7,15.0 \mathrm{~Hz})$, $3.69(3 \mathrm{H}, \mathrm{s}), 3.97(3 \mathrm{H}, \mathrm{s}), 4.85(1 \mathrm{H}, \mathrm{dt}, J=5.7,7.6 \mathrm{~Hz}$, changed to dd, $J=5.7,7.6 \mathrm{~Hz}$ on addition of $\left.\mathrm{D}_{2} \mathrm{O}\right), 6.15(1 \mathrm{H}$, 
br d, $J=7.6 \mathrm{~Hz}$, disappeared on addition of $\left.\mathrm{D}_{2} \mathrm{O}\right), 7.17(1 \mathrm{H}, \mathrm{s})$, $8.32(1 \mathrm{H}, \mathrm{s})$. High Resolution $\mathrm{MS} m / z$ : Calcd for $\mathrm{C}_{20} \mathrm{H}_{24} \mathrm{Br}_{2} \mathrm{~N}_{2} \mathrm{O}_{6}: 549.9960\left(\mathrm{M}^{+}\right), 547.9981\left(\mathrm{M}^{+}\right), 546.0011$ $\left(\mathrm{M}^{+}\right)$. Found: 549.9932, 547.9963, 546.0003. Optical Rotation $[\alpha]_{\mathrm{D}}{ }^{24}+12.9^{\circ}\left(\mathrm{CHCl}_{3}, \mathrm{c} 0.210\right)$.

Synthesis of 3 from 5 - A solution of $5(18.3 \mathrm{mg}, 0.03 \mathrm{mmol})$ in $\mathrm{CHCl}_{3}(3.2 \mathrm{~mL})$ was mixed with trifluoroacetic acid $(0.8$ $\mathrm{mL}$ ) under ice-cooling to prepare a $10 \%$ acidic solution. After stirring at room temperature for $12 \mathrm{~h}$, the reaction mixture was neutralized by adding saturated aqueous $\mathrm{NaHCO}_{3}$. The mixture was extracted with $\mathrm{CHCl}_{3}$. The extract was washed with brine, dried over $\mathrm{Na}_{2} \mathrm{SO}_{4}$, and evaporated under reduced pressure resulting in a colorless oil, which was column-chromatographed on $\mathrm{SiO}_{2}$ with $\mathrm{CHCl}_{3}-\mathrm{MeOH}$ (99:1, $\mathrm{v} / \mathrm{v}$ ) to produce $3(10.3 \mathrm{mg}, 70 \%)$. $3: \mathrm{mp} 174-175^{\circ} \mathrm{C}$ (colorless prisms, recrystallized from $\left.\mathrm{MeOH}-\mathrm{H}_{2} \mathrm{O}\right)$. IR ( $\left.\mathrm{KBr}\right)$ : 3363, 1745, 1716, 1660, $1647 \mathrm{~cm}^{-1}$. IR $\left(\mathrm{CHCl}_{3}\right): 1739,1674 \mathrm{~cm}^{-1}$. ${ }^{1} \mathrm{H}-\mathrm{NMR}\left(\mathrm{CDCl}_{3}\right) \delta: 1.98(3 \mathrm{H}, \mathrm{s}), 3.21(1 \mathrm{H}, \mathrm{dd}, J=4.6,14.0$ $\mathrm{Hz}), 3.24$ (1H, dd, $J=4.6,14.0 \mathrm{~Hz}), 3.70(3 \mathrm{H}, \mathrm{s}), 3.93(3 \mathrm{H}, \mathrm{s})$, $4.90(1 \mathrm{H}, \mathrm{dt}, J=7.6,4.6 \mathrm{~Hz}$, changed to t, $J=4.6 \mathrm{~Hz}$ on addition of $\left.\mathrm{D}_{2} \mathrm{O}\right), 6.05(1 \mathrm{H}, \mathrm{br} \mathrm{d}, J=7.6 \mathrm{~Hz}$, disappeared on addition of $\left.\mathrm{D}_{2} \mathrm{O}\right), 7.07(1 \mathrm{H}, \mathrm{s}), 7.48(1 \mathrm{H}, \mathrm{s}), 8.01(1 \mathrm{H}, \mathrm{br}$, disappeared on addition of $\left.\mathrm{D}_{2} \mathrm{O}\right)$. $\mathrm{MS} m / z: 450\left(\mathrm{M}^{+}\right), 448\left(\mathrm{M}^{+}\right)$, $446\left(\mathrm{M}^{+}\right)$. Anal. Calcd for $\mathrm{C}_{15} \mathrm{H}_{16} \mathrm{Br}_{2} \mathrm{~N}_{2} \mathrm{O}_{4}: \mathrm{C}, 40.20 ; \mathrm{H}, 3.60$; $\mathrm{N}, 6.25$. Found: C, 40.27; H, 3.71; N, 6.17. Optical Rotation $[\alpha]_{\mathrm{D}}^{27}+12.0^{\circ}(\mathrm{MeOH}, \mathrm{c} 0.217)$.

\subsection{Animals}

Both female and male goldfish (Carassius auratus) (20-30g) were purchased from a commercial source (Higashikawa Fish Farm, Yamatokoriyama, Japan) and used in the present study. The purchased goldfish were kept in an aquarium at $25^{\circ} \mathrm{C}$ with light $(12 \mathrm{~h})$ and dark $(12 \mathrm{~h})$ cycles for one week. After acclimation, the goldfish were used for experiment. All experimental procedures were conducted in accordance with the Guide for the Care and Use of Laboratory Animals of Tokyo Medical and Dental University.

Six female Sprague-Dawley rats, 5-weeks-old, were purchased from Charles River Japan (Kanagawa, Japan). They were fed a standard pelleted chow diet containing $1.25 \%$ calcium and $0.9 \%$ phosphorus (CRF-1: Oriental Yeast, Co., Ltd., Tokyo, Japan). The animals were housed under local vivarium conditions (temperature $23.3^{\circ} \mathrm{C}$, humidity $55 \%$, and a $12 \mathrm{~h}$ on/off light cycle), with free access to water. After allowing one week for adaptation to the new environment, the rats were used in the present study.

\subsection{Effect of Tryptophan Derivatives on ALP and TRAP Activities in the Cultured Goldfish Scales}

A $1 \%$ penicillin-streptomycin mixture (ICN Biomedicals Inc., OH, USA) was added to Eagle's Minimum Essential Medium (MEM; ICN Biomedicals Inc.). HEPES (20 mM; Research Organics Inc., OH, USA) was added to the medium and adjusted to $\mathrm{pH}$ 7.0. After filtration, MEM was used in this experiment for analyzing the effect of tryptophan derivatives on ALP and TRAP activities in the cultured goldfish scales.
Scales were collected from goldfish under anesthesia with ethyl 3-aminobenzoate, methanesulfonic acid salt (MS-222, Sigma-Aldrich, Inc., MO, USA) and incubated for $6 \mathrm{~h}$ in MEM supplemented with $10^{-6} \mathrm{M}$ tryptophan derivatives and compared with control (chemical-free medium).

The measurement methods of ALP and TRAP activities have been described by Suzuki and Hattori [3]. We detected the respective enzyme activity from single scales by transferring each scale into a 96-well-microplate and directly incubating it with the substrate in each well. The following procedure indicated how ALP activity was measured. Each scale was transferred to its own well in a 96-well microplate after measurement of the scale weight. A $200 \mu$ aliquot of 10 $\mathrm{mM}$ para-nitrophenyl-phosphate and alkaline buffer $(100 \mathrm{mM}$ Tris- $\mathrm{HCl}, \mathrm{pH} 9.5 ; 1 \mathrm{mM} \mathrm{MgCl} 2 ; 0.1 \mathrm{mM} \mathrm{ZnCl}_{2}$ ) were added to each well. The plate was then incubated at $20^{\circ} \mathrm{C}$ for $30 \mathrm{~min}$ while being shaken. After incubation, the reaction was stopped by adding $50 \mu \mathrm{l}$ of $2 \mathrm{~N} \mathrm{NaOH}$. One hundred and fifty microliters of a colored solution were transferred to a new plate, and the absorbance was measured at $405 \mathrm{~nm}$. The absorbance was converted into the amount of produced para-nitrophenol (pNP) calculated from a pNP standard curve. The results are shown as means \pm SEM of eight scales.

TRAP activity was measured using an acid buffer $(20 \mathrm{mM}$ tartrate in a $0.1 \mathrm{M}$ sodium acetate buffer, $\mathrm{pH}$ 5.3). Other procedures were the same as those for the measurement of ALP activity.

\subsection{Effect of BTryp on Bone Metabolism in the OVX Rats}

The rats were randomized by stratified weight method into two groups: OVX + vehicle $(\mathrm{n}=3)$ and OVX + BTryp (0.17 $\mathrm{mg} /$ head $)(\mathrm{n}=3)$. Operation methods were described by Iwamoto et al. [13]. BTryp was dissolved in dimethyl sulfoxide (DMSO) and injected orally daily $(0.17 \mathrm{mg} / \mathrm{head})$. In the control OVX rats, only DMSO was injected similarly. The injection was performed consecutively for six weeks, after which femoral bone dissections were carried out under general anesthesia [13]. The experiments using OVX rats were performed in the laboratory of HAMRI Co. Ltd. (Ibaraki, Japan). The animals were maintained according to the National Institutes of Health (NIH) Guide for Care and Use of Laboratory Animals, and the protocols were approved by the Laboratory Animal Care Committee of HAMRI Co. Ltd.

The dissected bone was analyzed by peripheral quantitative computed tomography (pQCT) scans. The pQCT scans were performed ex vivo using XCT-Research SA+ (Stratec Medizintechnik GMBH., Germany) software version Rev. 5.50e. The right distal femur was used for scans. Two slices were obtained; one in the metaphysic (at $3-4 \mathrm{~mm}$ from the distal growth plate to the proximal direction) and the other in the diaphysis (the central part of which is found by measuring the bone length). 


\subsection{Statistical Analysis}

In the scale in vitro assay, the values of experimental groups $(\mathrm{n}=8)$ were compared with those of controls $(\mathrm{n}=8)$ by Student's $t$-test. In the OVX rat experiment, comparison between control and experimental groups $(n=3)$ was performed by Student's $t$-test. The selected significance level was $p<0.05$.

\section{Results}

\subsection{Effect of Tryptophan Derivatives on ALP and TRAP Activities in Cultured Goldfish Scales}

We synthesized novel bromotryptophans, such as BTryp, $t$ BocBTryp, AllylBTryp, PropargylBTryp, and BnBTryp (Figure 1).

The effects of these chemicals on osteoblastic and osteoclastic activities were examined using the fish scales in vitro assay system, and the results are shown in Figure 2. All of chemicals increased osteoblastic activity. Among the derivatives, however, BTryp had the strongest effect on osteoblast activity. Significant differences between the control and experimental groups were only obtained with BTryp ( $p<$ $0.001), t$ BocBTryp $(p<0.05)$, and AllylBTryp $(p<0.05)$. On the other hand, the five tested chemicals had no significant effects on osteoclast activity under the present conditions.

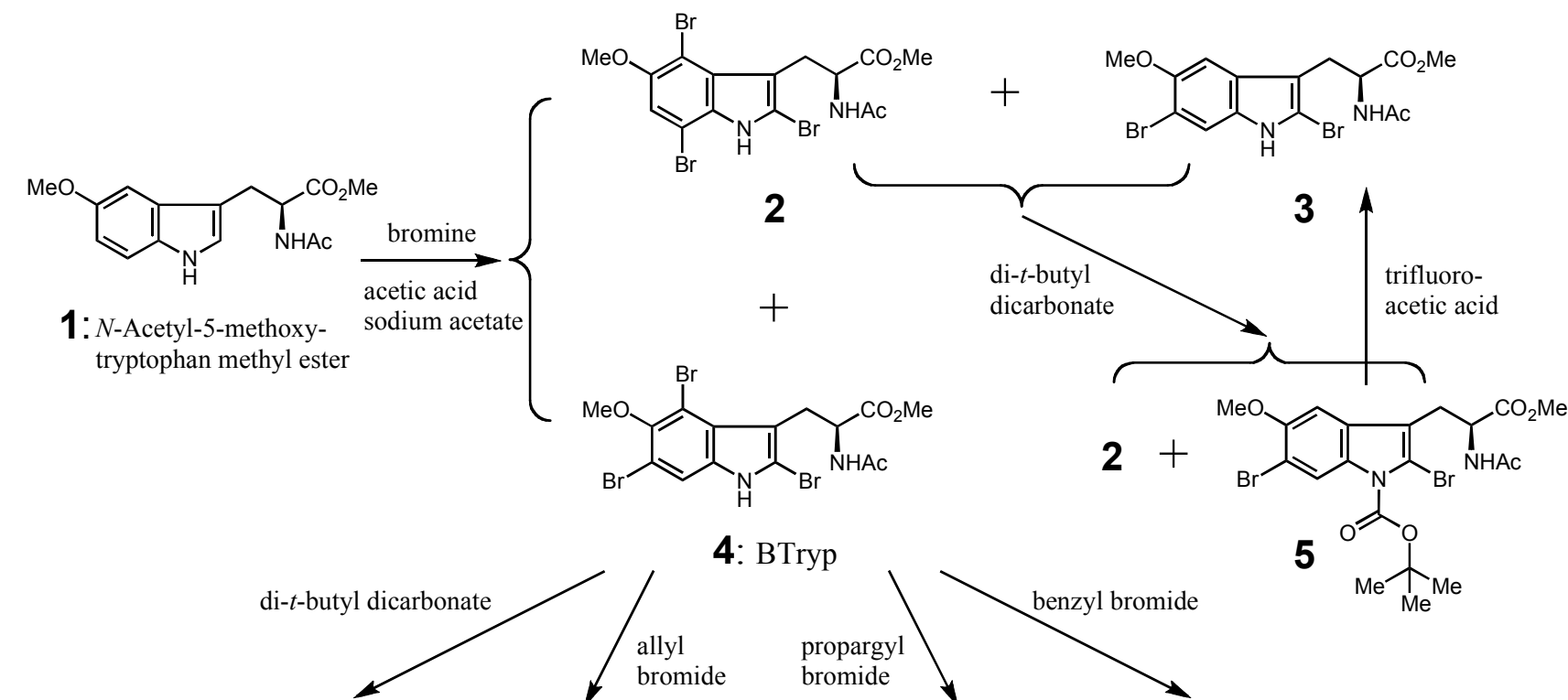<smiles>CNC(Cc1c(Br)n(C(=O)OC(C)(C)C)c2cc(Br)c(OC)c(Br)c12)C(C)=O</smiles>

6: $t$ BocBTryp<smiles>C=CCn1c(Br)c(CC(NC(C)=O)C(C)=O)c2c(Br)c(OC)c(Br)cc21</smiles>

7: AllylBTryp<smiles></smiles>

8: PropargylBTryp<smiles>[B]c1c2c(c(CC(N)=O)n1Cc1ccccc1)-c1cc(Br)c(OC)c(Br)c1-2</smiles>

9: BnBTryp

Fig. 1. Synthetic pathways and chemical structure of the bromotryptophan derivatives used in the present study. 4 BTryp: (S)-(+)-N-acetyl-2,4,6-tribromo-5-methoxytryptophan methyl ester; 6 tBocBTryp: (S)-(+)-N-acetyl-2,4,6-tribromo-1-t-butoxycarbonyl-5-methoxytryptophan methyl ester; 7 AllylBTryp: (S)-(+)-N-acetyl-1-allyl-2,4,6-tribromo-5-methoxytryptophan methyl ester; 8 PropargylBTryp: (S)-(+)-N-acetyl-2,4,6-tribromo-5-methoxy-1-propargyltryptophan methyl ester; 9 BnBTryp: (S)-(+)-N-acetyl-1-benzyl-2,4,6-tribromo-5-methoxytryptophan methyl ester. 
(A) ALP activity

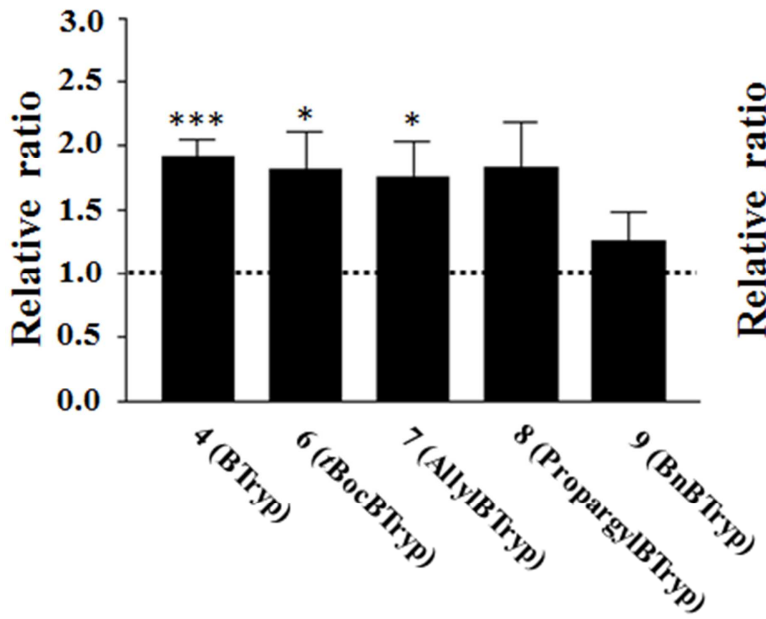

(B) TRAP activity

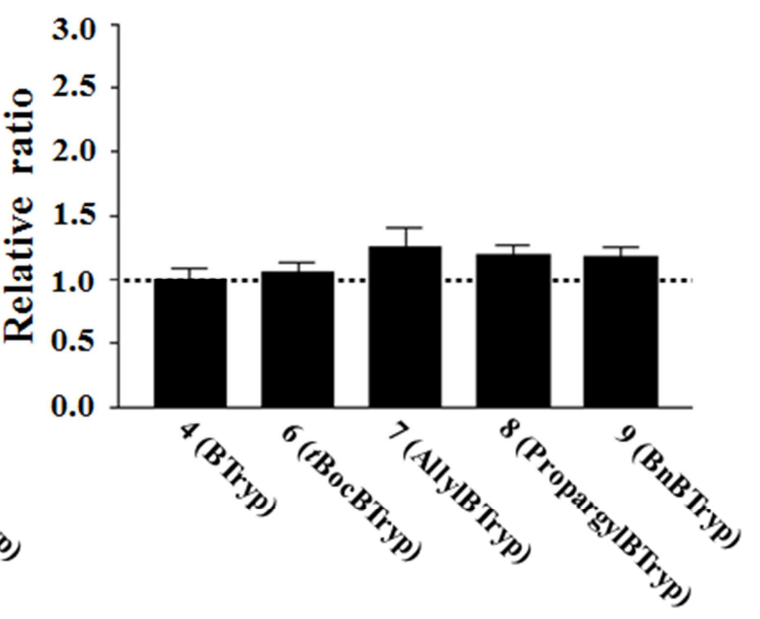

Fig. 2. Effects of bromotryptophan derivatives on osteoblastic (A) and osteoclastic (B) activities in cultured goldfish scales after 6 h of incubation. The value of each experimental group is expressed as the relative ratio for that of the control group. * and *** indicate statistically significant differences at $p<0.05$ and $p<$ 0.001 , respectively, compared to respective value of the control scales. The data are expressed as the means $\pm S E M(n=8)$.

\subsection{Effect of BTryp on Bone Metabolism in the OVX Rats}

BTryp $(0.17 \mathrm{mg} / \mathrm{head})$ was administrated to OVX rats after which the femoral bone was analyzed for bone density and mechanical properties. The results are indicated in Tables 1 and 2. Both trabecular bone mineral density (Fig. 3A) and stress-strain index (Fig. 3B) of the femoral metaphysis of BTryp-treated OVX rats were significantly higher than those

(A)

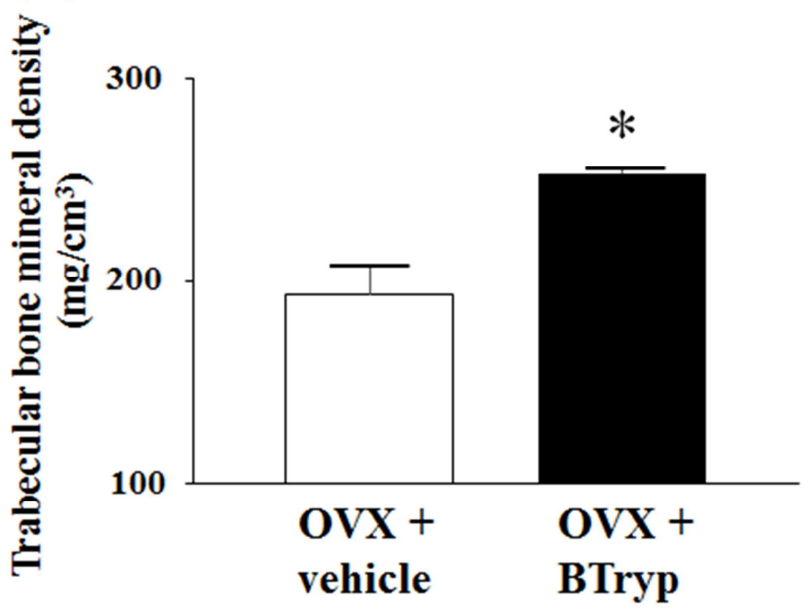

of OVX rats. BTryp treated animals showed trends for increased total area. On the other hand, BTryp did not influence bone mineral density, area, thickness, periosteal circumference, endosteal circumference, and stress-strain index in the femoral diaphysis of OVX rats under the present experimental conditions (Table 2 ).

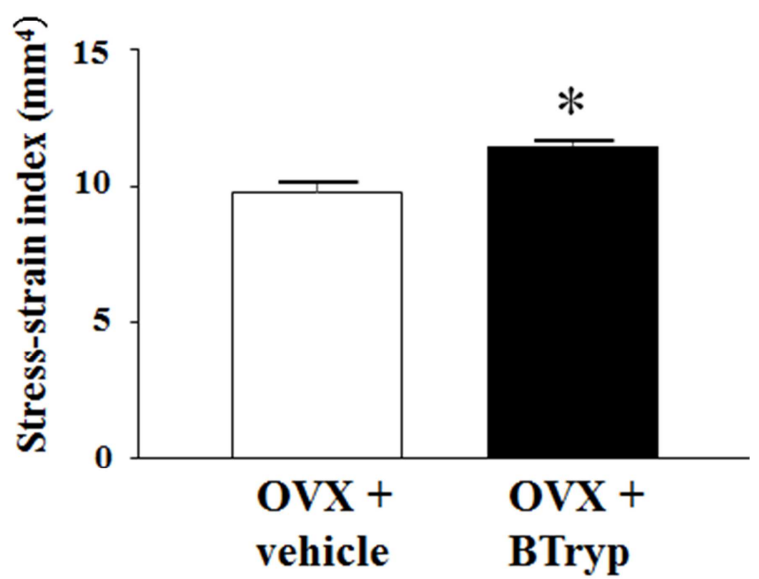

Fig. 3. Effects of BTryp on trabecular bone mineral density (BMD) (A) and stress-strain index (SSI) (B) of the femoral metaphysis in OVX rats. * indicates statistically significant differences at $p<0.05$, from the respective value in the OVX rats. The data are expressed as the means $\pm S E M(n=3)$.

Table 1. Analysis of bone mineral density (BMD), area, and stress-strain index (SSI) in femoral metaphysis of OVX rats or Btryp-treated OVX rats.

\begin{tabular}{|c|c|c|c|c|c|c|}
\hline \multirow{3}{*}{ Group } & \multirow{3}{*}{$\begin{array}{l}\text { Sample } \\
\text { numbers }\end{array}$} & \multicolumn{5}{|c|}{ Metaphysis } \\
\hline & & \multicolumn{2}{|c|}{ BMD $\left(\mathrm{mg} / \mathrm{cm}^{3}\right)$} & \multicolumn{2}{|c|}{$\operatorname{Area}\left(\mathrm{mm}^{2}\right)$} & \multirow{2}{*}{$\begin{array}{l}\text { SSI }\left(\mathrm{mm}^{4}\right) \\
\text { Polar }\end{array}$} \\
\hline & & Total & Trabecular & Total & Trabecular & \\
\hline OVX + Vehicle & 3 & $473.1 \pm 17.2$ & $192.9 \pm 14.5$ & $21.69 \pm 0.95$ & $9.47 \pm 0.89$ & $9.801 \pm 0.337$ \\
\hline OVX + BTryp & 3 & $520.4 \pm 18.6$ & $253.4 \pm 1.7 *$ & $23.67 \pm 0.79$ & $7.44 \pm 0.27$ & $11.474 \pm 0.204 *$ \\
\hline
\end{tabular}

*: significantly different $(p<0.05)$ between OVX rats and OVX + BTryp-treated rats. 
Table 2. Analysis of bone mineral density (BMD), area, thickness, periosteal circumference, endosteal circumference, and stress-strain index (SSI) in femoral diaphysis of OVX rats or BTryp-treated OVX rats.

\begin{tabular}{|c|c|c|c|c|c|c|c|}
\hline \multirow{3}{*}{ Group } & \multirow{3}{*}{$\begin{array}{l}\text { Sample } \\
\text { numbers }\end{array}$} & \multicolumn{5}{|c|}{ Diaphysis } & \multirow[b]{2}{*}{$\operatorname{SSI}\left(\mathrm{mm}^{4}\right)$} \\
\hline & & BMD & Area & Thickness & $\begin{array}{l}\begin{array}{l}\text { Periosteal } \\
\text { circumference }\end{array} \\
\end{array}$ & $\begin{array}{l}\begin{array}{l}\text { Endosteal } \\
\text { circumference }\end{array} \\
\end{array}$ & \\
\hline & & $\left(\mathrm{mg} / \mathrm{cm}^{3}\right)$ & $\left(\mathrm{mm}^{2}\right)$ & $(\mathbf{m m})$ & $(\mathbf{m m})$ & $(\mathbf{m m})$ & Polar \\
\hline OVX + Vehicle & 3 & $1265.7 \pm 9.4$ & $5.55 \pm 0.01$ & $0.551 \pm 0.012$ & $11.819 \pm 0.201$ & $8.360 \pm 0.270$ & $6.753 \pm 0.380$ \\
\hline OVX + BTryp & 3 & $1254.9 \pm 8.6$ & $5.50 \pm 0.10$ & $0.552 \pm 0.022$ & $11.729 \pm 0.268$ & $8.260 \pm 0.391$ & $6.877 \pm 0.605$ \\
\hline \multicolumn{8}{|c|}{ Data as mean \pm SEM } \\
\hline
\end{tabular}

\section{Discussion}

We successfully synthesized novel tryptophan derivatives (Fig. 1) and indicated that some derivatives (BTryp, $t$ BocBTryp, and AllylBTryp) stimulate osteoblast activity in goldfish scales (Fig. 2A). We previously demonstrated that the osteogenesis of a regenerating scale is quite similar to that of mammalian membrane bone, providing a good model of osteogenesis [4]. As described above, we previously demonstrated that parathyroid hormone [7] and calcitonin [2] act on osteoblasts and osteoclasts in teleost scales in a similar manner as that in mammalian systems. We have also reported that melatonin, a major hormone secreted from the pineal gland, suppressed both osteoblast and osteoclast functions [3]. This was the first report related to the function of melatonin in osteoclasts and the inhibitory effect of melatonin in osteoblasts in any vertebrate species. Thus, we discovered novel functions of melatonin by using this assay system. We have previously investigated osteoblast and osteoclast responses to endocrine disrupters, such as bisphenol-A [14] and tributyltin [15], and heavy metals, such as cadmium and organic mercury [16]. Moreover, we indicated that TRAP activity in the scale is altered by cadmium (even at $10^{-13} \mathrm{M}$ ) [16]. Considering these results together with the present data, our scale assay system may be useful for the analysis of effect of several substances, including hormones and environmental pollutants, on bone metabolism.

The results obtained with our scale assay system were confirmed in vivo using an OVX rat model of post-menopausal osteoporosis (Table 1). BTryp promoted both increased trabecular bone mineral density and stress-strain index of the femoral metaphysis of OVX rats (Fig. 3). Therefore, BTryp may have therapeutic value towards bone formation. Bisphosphonates, osteoporosis-fighting drugs, are the mainstay of treatment for postmenopausal osteoporosis However, some side effects of bisphosphonates have been reported. Adverse drug reactions to bisphosphonates include gastrointestinal effects, acute phase reactions, musculoskeletal pain, atrial fibrillation, subtrochanteric or diaphyseal fracture, osteonecrosis of the jaw, cutaneous hypersensitivity reactions, and renal impairment [17]. BTryp may therefore have potential use in the treatment of osteoporosis as a substitute for bisphosphonates.

An interaction between osteoclasts and osteoblasts was also recently noted in mammals, and both actions must be considered when examining bone metabolism [18, 19].
RANK and RANKL have been identified in osteoclasts and osteoblasts, respectively [20]. Multi-nucleated osteoclasts (an active type of osteoclasts) are activated by the binding of RANKL to RANK [20]. In OVX rats, the injection of BTryp suppressed bone resorption and augmented some osteoblastic markers indicative of bone formation. Since this novel bromotryptophan derivative was found to have an effect on the osteoblasts of goldfish scales in an in vitro assay, this chemical might suppress RANKL mRNA expression in osteoblasts and augment bone mineral density and bone strength in OVX rats. Additional studies will be required to examine the detailed mechanisms of the bromotryptophan derivatives in animal models of bone disease.

\section{Acknowledgments}

This study was supported in part by grants to N.S. (Grant-in-Aid for Scientific Research [C] No. 24620004 by JSPS), to T.S. (Grant-in-Aid for Young Scientists [B] No. 40378568 by JSPS), to H.M. (Grant-in-Aid for Scientific Research [C] No. 23592727 by JSPS), to Y.T. (Grant-in-Aid for Exploratory Research No. 26560205 by JSPS), to K.K. (Grant-in-Aid for Scientific Research [C] No. 24500848 by JSPS), and to A.H. (Grant-in-Aid for Scientific Research [C] No. 24570068 by JSPS). This study was performed under the cooperative research program of the Institute of Nature and Environmental Technology, Kanazawa University (Accept No. $1)$.

\section{References}

[1] J. Bereiter-Hahn, L. Zylberberg, "Regeneration of teleost fish scale," Comp Biochem Physiol Part A, 1993, 105, pp. 625-641.

[2] N. Suzuki, T. Suzuki, T. Kurokawa, "Suppression of osteoclastic activities by calcitonin in the scales of goldfish (freshwater teleost) and nibbler fish (seawater teleost)," Peptides, 2000, 21, pp. 115-124.

[3] N. Suzuki, A. Hattori, "Melatonin suppresses osteoclastic and osteoblastic activities in the scales of goldfish," J Pineal Res, 2002, 33, pp. 253-258.

[4] H. Yoshikubo, N. Suzuki, K. Takemura, M. Hoso, S. Yashima, S. Iwamuro, Y. Takagi, M.J. Tabata, A. Hattori, "Osteoblastic activity and estrogenic response in the regenerating scale of goldfish, a good model of osteogenesis," Life Sci, 2005, 76, pp. 2699-2709. 
[5] N. Suzuki, K. Kitamura, T. Nemoto, N. Shimizu, S. Wada, T. Kondo, M.J. Tabata, F. Sodeyama, K. Ijiri, A. Hattori, "Effect of vibration on osteoblastic and osteoclastic activities: analysis of bone metabolism using goldfish scale as a model for bone," Adv Space Res, 2007, 40, pp. 1711-1721.

[6] E. de Vrieze, F. Sharif, J.R. Metz, G. Flik, M.K. Richardson, "Matrix metalloproteinases in osteoclasts of ontogenetic and regenerating zebrafish scales," Bone, 2011, 48, pp. 704-712.

[7] N. Suzuki, J.A. Danks, Y. Maruyama, M. Ikegame, Y. Sasayama, A. Hattori, N. Nakamura, M.J. Tabata, T. Yamamoto, R. Furuya, K. Saijoh, H. Mishima, A.K. Srivastav, Y. Furusawa, T. Kondo, Y. Tabuchi, I. Takasaki, V.S. Chowdhury, K. Hayakawa, T.J. Martin, "Parathyroid hormone 1 (1-34) acts on the scales and involves calcium metabolism in goldfish," Bone, 2011, 48, pp. 1186-1193.

[8] K. Azuma, M. Kobayashi, M. Nakamura, N. Suzuki, S. Yashima, S. Iwamuro, M. Ikegame, T. Yamamoto, A. Hattori, "Two osteoclastic markers expressed in multinucleate osteoclasts of goldfish scales," Biochem Biophys Res Commun, 2007, 362, pp. 594-600.

[9] T.A. Thamamongood, R. Furuya, S. Fukuba, M. Nakamura, N. Suzuki, A. Hattori, "Expression of osteoblastic and osteoclastic genes during spontaneous regeneration and autotransplantation of goldfish scale: a new tool to study intramembranous bone regeneration," Bone, 2012, 50, pp.1240-1249.

[10] A. Berg, "Studies on the metabolism of calcium and strontium in freshwater fish I: relative contribution of direct and intestinal absorption,” Mem Ist Ital Idrobiol, 1968, 23, pp. 161-196.

[11] Y. Mugiya, N. Watabe, "Studies on fish scale formation and resorption II: effect of estradiol on calcium homeostasis and skeletal tissue resorption in the goldfish, Carassius auratus, and the killifish, Fundulus heteroclitus," Comp Biochem Physiol Part A, 1977, 57, pp. 197-202.

[12] M. Somei, Y. Fukui, "Nucleophilic substitution reaction of 1-hydroxytryptophan and 1-hydroxytryptamine derivatives regioselective syntheses of 5-substituted derivatives of tryptophan and tryptamine" Heterocycles, 1993, 36, pp. 1859-1966.

[13] J. Iwamoto, A. Seki, T. Takeda, Y. Sato, H. Yamada, J.K. Yeh, "Comparative effects of alendronate and alfacalcidol on cancellous and cortical bone mass and bone mechanical properties in ovariectomized rats," Exp Anim, 2006, 55, pp. 357-367.

[14] N. Suzuki, A. Hattori, "Bisphenol A suppresses osteoclastic and osteoblastic activities in the cultured scales of goldfish," Life Sci, 2003, 73, pp. 2237-2247.

[15] N. Suzuki, M.J. Tabata, A. Kambegawa, A.K. Srivastav, A. Shimada, H. Takeda, M. Kobayashi, S. Wada, T. Katsumata, A. Hattori, "Tributyltin inhibits osteoblastic activity and disrupts calcium metabolism through an increase in plasma calcium and calcitonin levels in teleosts," Life Sci, 2006, 78, pp. 2533-2541.

[16] N. Suzuki, M. Yamamoto, K. Watanabe, A. Kambegawa, A. Hattori, "Both mercury and cadmium directly influence calcium homeostasis resulting from the suppression of scale bone cells: the scale is a good model for the evaluation of heavy metals in bone metabolism," J Bone Miner Metab, 2004, 22, 439-446.

[17] R, Rizzoli, J.Y. Reginster, "Adverse drug reactions to osteoporosis treatments," Expert Rev Clin Pharmacol, 2011, 4, pp. 593-604.

[18] T. Suda, N. Takahashi, N. Udagawa, E. Jimi, M.T. Gillespie, T.J. Martin, "Modulation of osteoclast differentiation and function by the new members of the tumor necrosis factor receptor and ligand families," Endocr Rev, 1999, 20, pp. 345-357.

[19] S.C. Manolagas, "Birth and death of bone cells: basic regulatory mechanisms and implications for the pathogenesis and treatment of osteoporosis," Endocr Rev, 2000, 21, pp. 115-137.

[20] S.L. Teitelbaum, "Bone resorption by osteoclasts," Science, 2000, 289, pp. 1504-1508. 